\title{
Axenfeld-Rieger-szindróma: szemészeti és fogászati diagnosztikai és kezelési lehetőségek
}

\author{
Bausz Mária dr. ${ }^{1}$ - Csidey Mária dr. ${ }^{1}$ - Csákány Béla dr. ${ }^{1}$ \\ Németh Orsolya dr. ${ }^{2}$ - Nagy Zoltán Zsolt dr. ${ }^{1}$ - Maka Erika dr. ${ }^{1}$ \\ 'Semmelweis Egyetem, Általános Orvostudományi Kar, Szemészeti Klinika, Budapest \\ ${ }^{2}$ Semmelweis Egyetem, Fogorvostudományi Kar, Fogászati és Szájsebészeti Oktató Intézet, Budapest
}

\begin{abstract}
Az Axenfeld-Rieger-szindróma ritka betegség. A közlemény bemutatja a klinikai megjelenési formáit, a diagnosztikus és terápiás lehetőségeket. A szemgolyó elülső szegmentumát érintő fejlődési rendellenességek vizsgálata a hagyományos biomikroszkópos vizsgálat mellett digitális kamerával is történhet, mely a csarnokzugi képleteket nagy nagyításban, éles képet mutatva tudja megjeleníteni. Az elülső szegmentum leképezését segítő optikaikoherenciatomográfia és ultrahang-biomikroszkópia a fejlődési rendellenességnek és a csarnokvíz-elvezető sönt tubusának vizsgálatára, megjelenítésére is alkalmas. A szemnyomást a gyermek kooperációjának függvényében többféle módon mérhetjük. A szabálytalan alakú, sokszor csak résnyi pupilla, valamint a szemnyomás-emelkedés miatt szemészeti beavatkozás lehet szükséges. A korai pupillaképzés az amblyopia megelőzését, az antiglaucomás mútétek (trabeculectomia, hosszú tubusú sönt implantációja) pedig a látási funkciók megórzését szolgálják. A szemészeti mútéteket akár már néhány hónapos korban szükséges elvégezni altatásban. A maxillahypoplasia és a fogászati fejlódési anomáliák miatt kétirányú panoráma-röntgenfelvétel szükséges. Többlépcsős fogászati konzervatív és restoratív kezelés hozhat eredményt. A diagnózis felállitása és a kezelés is multidiszciplináris megközelítést igényel. Gyermekgyógyász, genetikus, kardiológus, fogász-szájsebész és gyermekszemész együttes munkája biztosíthat megfelelő eredményt.
\end{abstract} Orv Hetil. 2021; 162(5): 192-199.

Kulcsszavak: Axenfeld-Rieger-szindróma, elülső szegmentum, fogazat

\section{Axenfeld-Rieger syndrome: ophthalmological and dental diagnostic and therapeutic options}

Axenfeld-Rieger syndrome is a rare disease. Our paper presents its clinical manifestations, diagnostic and therapeutic options. Due to maxillary hypoplasia and dental developmental anomalies, bidirectional panoramic radiography is required. Multi-stage dental conservative and restorative treatment can provide better results. In addition to traditional biomicroscopic examination, developmental abnormalities affecting the anterior segment of the eye can also be examined with a digital camera, which can display the angle of the anterior chamber at high magnification, with a sharp image. Anterior segment optical coherence tomography and ultrasound biomicroscopy are also suitable for the examination and display of developmental abnormalities and drainage shunt tubes. Intraocular pressure can be measured in several ways depending on the child's cooperation. Due to the irregular shape of the pupil, often with only a slit aperture, and an increase in intraocular pressure, ophthalmic intervention may be required. The pupilloplasty is important preventing amblyopia prevention and early glaucoma surgery (trabeculectomy, shunt implantation) helps to preserve visual function. Eye surgeries need to be performed under anaesthesia, sometimes at few months of age. Both diagnosis and treatment require a multidisciplinary approach. The joint work of a paediatrician, geneticist, cardiologist, dental-oral surgeon and paediatric ophthalmologist may provide a satisfactory result.

Keywords: Axenfeld-Rieger syndrome, anterior segment, dentition

Bausz M, Csidey M, Csákány B, Németh O, Nagy ZZs, Maka E. [Axenfeld-Rieger syndrome: ophthalmological and dental diagnostic and therapeutic options]. Orv Hetil. 2021; 162(5): 192-199.

(Beérkezett: 2020. május 26.; elfogadva: 2020. augusztus 13.) 


\section{Rövidítések}

CBCT $=$ (cone-beam computed tomography) kúpsugaras komputertomográfia; $\mathrm{MR}=$ (magnetic resonance $)$ mágneses rezonancia; $\mathrm{OCT}=($ optical coherence tomography $)$ optikaikoherencia-tomográfia; UBM = ultrahang-biomikroszkópia

Az Axenfeld-Rieger-szindróma ritka spektrumbetegség, előfordulási gyakorisága 1/200 000. Autoszomális domináns öröklésmenetet mutat, de előfordulnak sporadikus esetek is. A kórkép első leírója Karl Theodor Paul Polykarpus Axenfeld német szemorvos volt, aki 1920ban posterior embryotoxont és azzal összeköttetésben lévő perifériás iridocornealis adhaesiókat említ. Majd Herwigh Rieger 1934-ben irishypoplasia, corectopia és microcoria jelenlétével egészíti ki a jellemzőket. Az Axenfeld-Rieger-szindróma megnevezés 1985-től használatos [1]

Axenfeld-anomália: posterior embryotoxon, perifériás iridocornealis adhaesio, előrehelyezett Schwalbe-vonal.

Rieger-anomália: az Axenfeld-anomália tünetei mellett irishypoplasia, corectopia és polycoria.

Rieger-szindróma: szemészeti eltérések szisztémás eltérésekkel.

Axenfeld-Rieger-szindróma: Axenfeld-anomália + Rieger-szindróma.

Megjegyzés: az angol irodalom elsősorban a Riegerszindróma elnevezést használja Axenfeld nélkül.

A gyermekszemész feladata az elülső szegmentumot érintő fejlődési rendellenességek által okozott eltérések miatti kezelés, mely nemritkán mútéti. Ilyen beavatkozás az elhúzott, ezáltal nem centrális szembogár miatti pupillaképzés, valamint az esetek mintegy $50 \%$-ában előforduló glaucoma miatt szükségessé váló mútét. Amennyiben a fent említett arckoponya- és fogászati rendellenességek is jelen vannak, akkor jól felállított kezelési terv szerint szükséges elvégezni az állkapocs rekonstrukciós kezelését és a fogazat pótlását. Ideális esetben az érintett gyermekek már néhány hónapos korban szakértő gyermekgyógyász, gyermekszemész, gyermekfogász látókörébe kerülnek.

A rendellenesség érinti az arc konfigurációját, a fogak alakját és helyzetét, a szemgolyók elülső szegmentumát. A csarnokzugi fejlődési rendellenességek miatt az érintettek felénél glaucoma alakul ki [2]. A tünetegyüttes részét képezheti a periumbilicalis bőr involutiójának elmaradása, anusatresia vagy -szúkület, valamint „empty sella" és parasellaris arachnoidealis cysták jelenléte is. A klinikai megjelenés sokszínúségét a lehetséges génmutációk (PIX2, FOXOIA, FOXC1) magyarázzák. A diagnózis felállítását genetikai vizsgálatok segíthetik.

\section{Szemészeti jellemzők}

A szemgolyó elülső szegmentumának fejlődési zavarait nagyrészt a dúcléceredetú sejtek abnormális migrációja és differenciálódása okozza. Az Axenfeld-Rieger-szind- róma mint spektrumbetegség szemészeti szempontból is változatos képet mutathat.

A posterior embryotoxon a szindróma egyik jellegzetessége. Anatómiailag előrehelyezett Schwalbe-vonal, azaz a Descemet-membrán végződése. Lehet igen vékony, irreguláris és vaskos is. Háromszor gyakrabban figyelhetố meg temporalisan, mint nasalisan. A normálszemek 8-15\%-ában észlelhető. Az Alagille-szindróma (újszülöttkori cholestasis) fó szemészeti tünete, ezen betegek 95\%-ában látható.

A posterior embryotoxonhoz vékony szivárványhártya-szálcsák húzódhatnak, vagy szélesebb perifériás iridocornealis adhaesio is megfigyelhető (perifériás anterior synechia). Ezen eltérések a csarnokzugban helyezkednek el. Előfordulhat goniodysgenesis is: az iris a sclerasarkantyú előtt a trabecularis hálózaton eredhet; a trabecularis hálózat is abnormális lehet, a Schlemm-csatorna akár hiányozhat is. A csarnokzugi eltérések az érintettek felénél glaucomát okoznak.

A szivárványhártya elhúzottá válhat a csarnokzug irányába, rámutatva a vaskosabb iridocornealis adhaesióra. Helyenként az iris hypoplasiás, ezért különböző nagyságú és alakú lyukakat is megfigyelhetünk.

A pupilla rendellenessége változatos formát mutat. A kerek, centrális szembogár helyett a csarnokzug irányába, a központi részból elhúzott lehet (dyscoria: a pupilla nem kerek; corectopia: a pupilla nem centrális), extrém esetben csak egy rés látható. Máskor több szabálytalan vagy nagyobb nyílás figyelhető meg az atrophiás szivárványhártyában (pseudopolycoria) (1. táblázat).

A szemészeti szakirodalomban leírtak extraocularis izomhypoplasiát is, bár a szindróma részét képező eltérések dúcléceredetû́ anomáliák, az izomeltérések pedig mesodermalis eredetúek [3]. Vitreoretinopathia következtében kialakult retinaleválás előfordulására is találhatunk példát [4].

Szemészeti szempontból a differenciáldiagnosztikában felmerülő kórkép az iridocornealis endothelialis szindróma három típusa: a Chandler-szindróma, az essentialis irisatrophia és a Cogan-Reese-szindróma.

1. táblázat |Az Axenfeld-Rieger-szindróma szemészeti tünetei

\begin{tabular}{ll}
\hline Szaruhártya & $\begin{array}{l}\text { Microcornea vagy megalocornea is előfordulhat } \\
\text { Posterior embryotoxon (7. ábra) }\end{array}$ \\
\hline $\begin{array}{l}\text { Szivárvány- } \\
\text { hártya }\end{array}$ & $\begin{array}{l}\text { Stromahypoplasia (az iris sima, kripták nem láthatók) } \\
\text { Lyukak } \\
\text { A zug irányába elhúzott irisszövet }\end{array}$ \\
\hline Pupilla & $\begin{array}{l}\text { Pseudopolycoria (irislyukak) (1. ábra) } \\
\text { Corectopia }\end{array}$ \\
& Dyscoria \\
\hline Csarnokzug & $\begin{array}{l}\text { Magas irisinsertio } \\
\text { Abnormális szövet a zugban (8. ábra) } \\
\end{array}$ \\
\end{tabular}




\section{Betegadatok, szemészeti gondozás és kezelés}

Klinikánkon 7 gyermeket gondozunk Axenfeld-Riegerszindróma diagnózisával.

1. eset (fiú): A klinikailag legmarkánsabb tüneteket mutató fiúgyermek 6 éves korában került klinikánkra. Abban az évben mindkét szemen trabeculectomia történt, mivel konzervatív kezeléssel a szemnyomás nem volt befolyásolható. 7 éves korában a bal szemen Ahmed-sönt implantációjára kényszerültünk, ennek ellenére a szemnyomás jelenleg sem normális, további beavatkozások lesznek szükségesek.

1 éves korában omphalokele miatt, 2 éves korában köldöksipoly miatt történt mútét. Fogászati statusa is ennek a betegünknek problémás a leginkább (1-6. ábra).

Követési idő: 5 év.
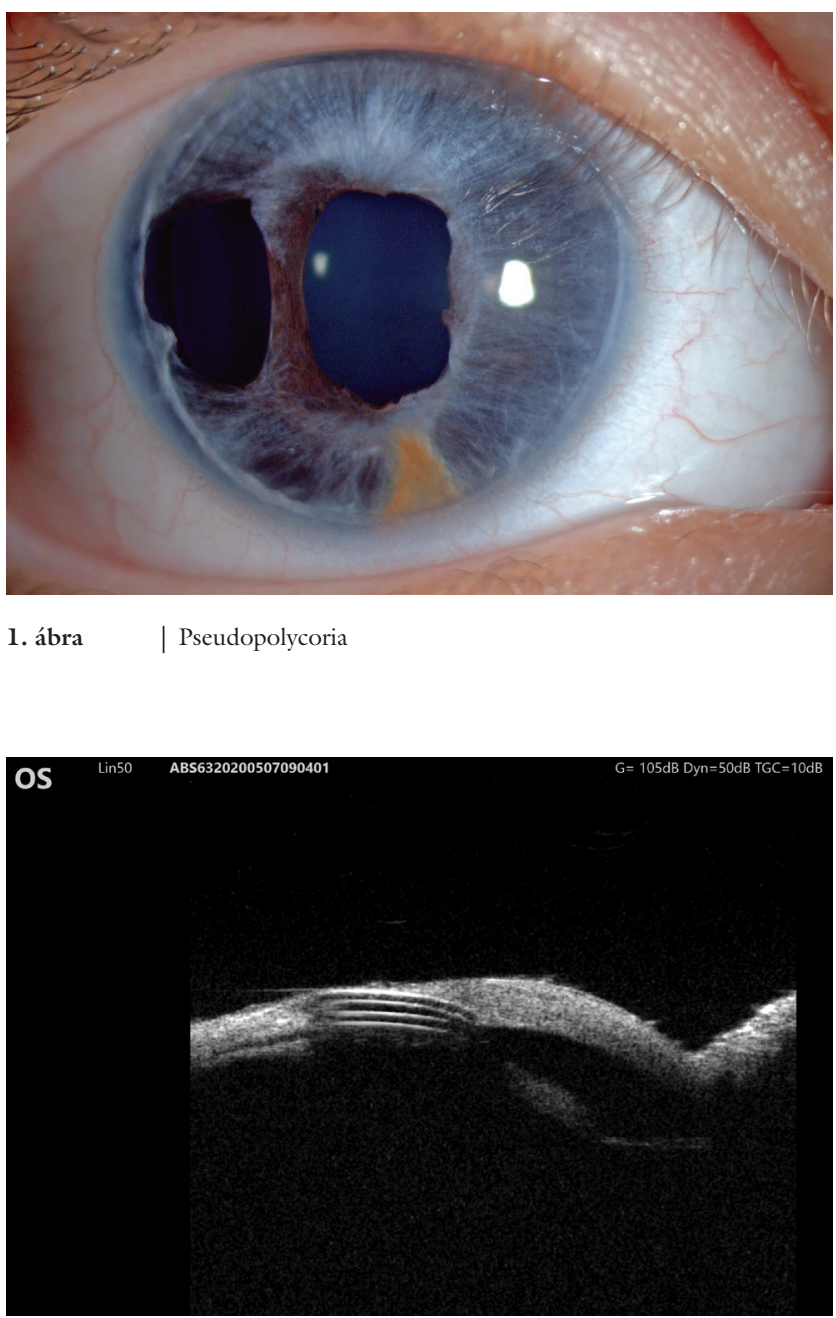

2. ábra A sönt elülső csarnokból induló tubusának UBM-mel készült hosszmetszeti képe

$\mathrm{UBM}=$ ultrahang-biomikroszkópia

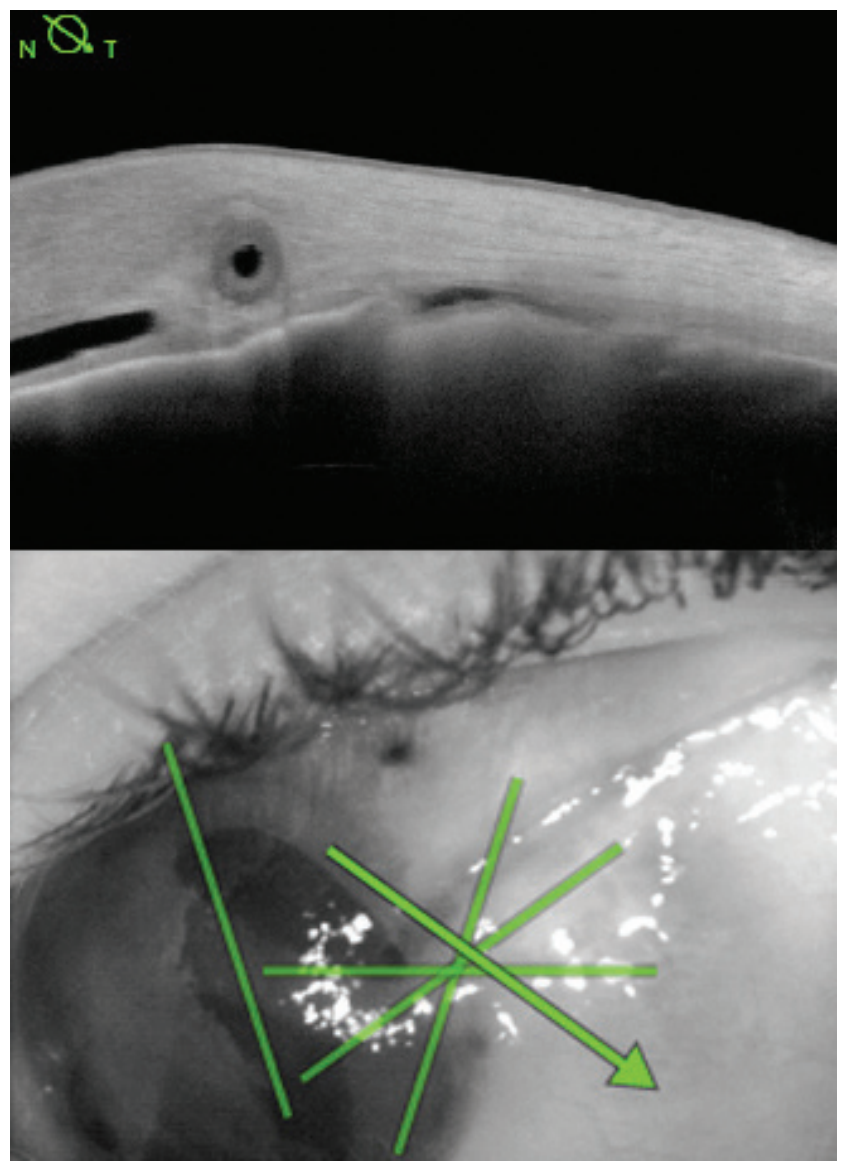

3. ábra

A tubus elülsőszegmentum-OCT-vel készült keresztmetszeti képe a sclerocornealis határon

OCT $=$ optikaikoherencia-tomográfia

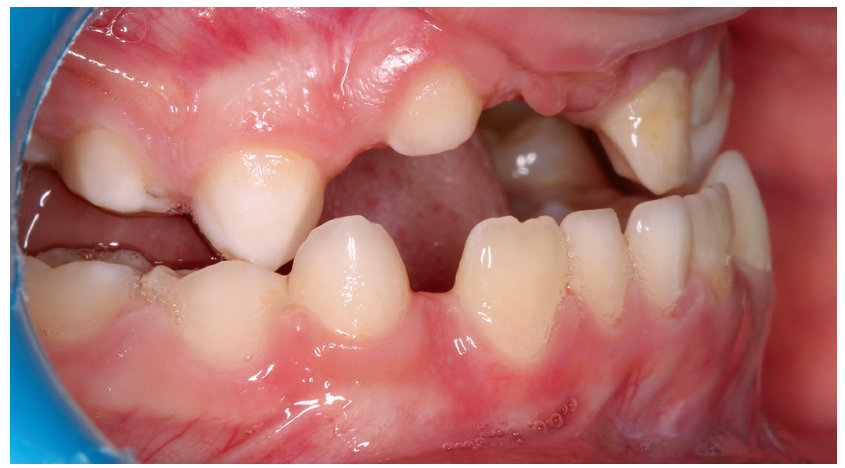

4. ábra

| Maxillahypoplasia a vegyes fogazat időszakában jobb oldalról

2. eset (fiú): A magas szemnyomások miatt 13 és 14 hónapos korában mindkét szemén trabeculectomiát végeztünk. 2 éves korában a bal oldalon pupillaképzés történt (az elhúzott pupilla miatt). 7 éves korában Ahmed-sönt implantációján esett át, jelenleg a szemnyomás kompenzált.

2013-ban kardiológiai osztályon pitvari sövényhiány zárása történt. Egyéb tünet, a köldökbőr visszahúzódásának elmaradása is észlelhető.

Követési idő: 10 év. 


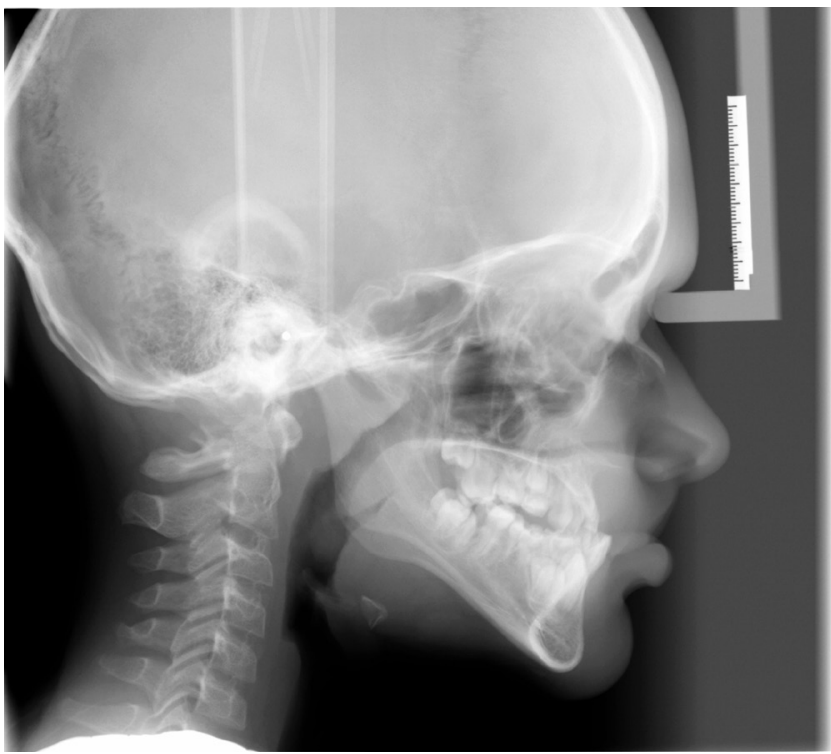

5. ábra

Teleröntgen-felvétel, cefalometriai analízis segítségével megállapítható a maxilla hypoplasiája. Jól megfigyelhető a mandibulának a maxillához való helyzete, ami a hypoplasia miatt a III osztályú harapás kialakulásához vezet

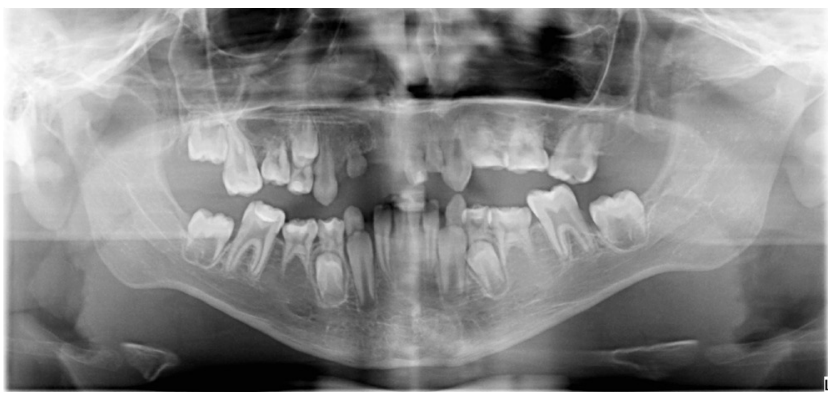

6. ábra

Orthopantomogram-felvétel, melynek segítségével láthatók a szájban levő tejfogak és az alveolusban fejlődő maradandó fogak csírái. Ennek segítségével prognosztizálni lehet, hogy mi várható a maradó fogak tekintetében. A felső állcsonton jobb elsó kisőrlő, első nagyőrlő, második nagyőrlő, bal felső első nagyőrlô maradó fogak láthatók. Az alsó állcsonton a második kisőrlők aplasiája figyelhető meg

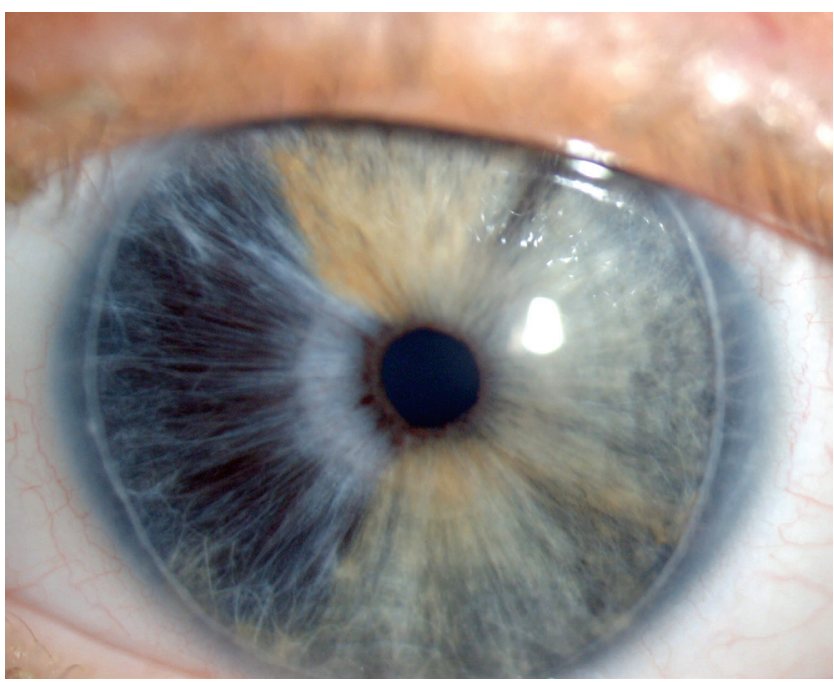

\begin{tabular}{l|l} 
7. ábra & Posterior embryotoxon és irishypoplasia
\end{tabular}

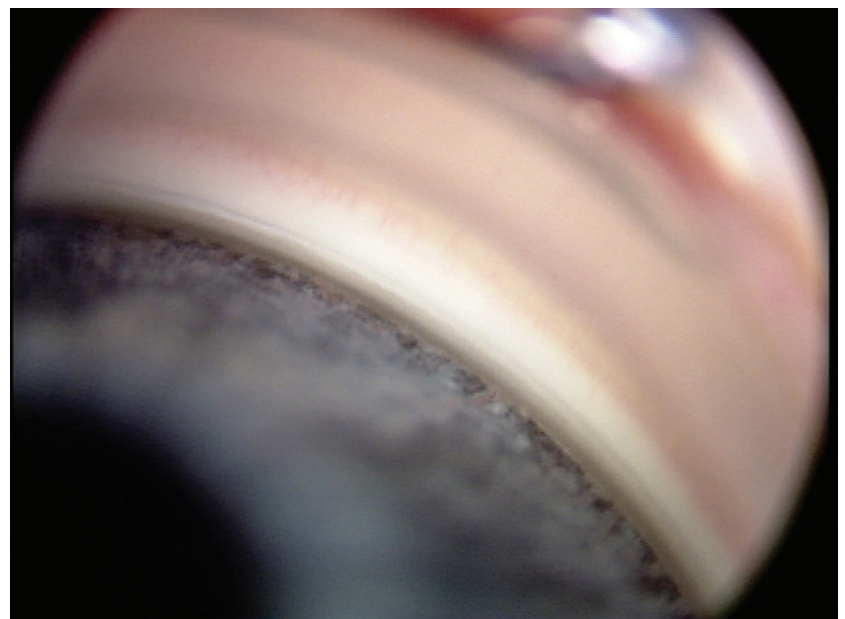

8. ábra | Goniodysgenesis: a csarnokzugban amorf, szürkés szövet

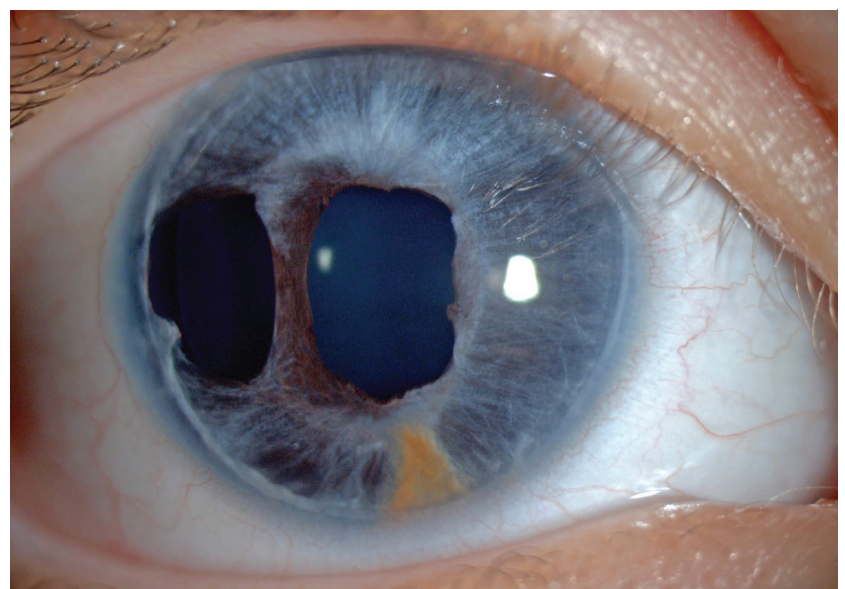

9. ábra

Posterior embryotoxon, irisatrophia. Dyscoria és corectopia miatt végzett pupillaplastica utáni állapot: 'limbus-parallel' iridotomia hatására a pupilla centrálissá vált

3. eset (fiú): 4 éves korában jelentkezett klinikánkon: a jobb oldali bulbusban az elülső szegmentum jellegzetes anomáliáját, elhúzott pupillát észleltünk, emiatt 4 éves korában pupillaképzés történt. Szemnyomása szemcseppekkel jelenleg is kompenzált. Általános tünetek: microcephalia, megkésett növekedés, megkésett fogzás, corpus callosum hypoplasia, cerebellaris hypoplasia (7-9. ábra).

Követési idő: 8 év.

4. eset (leány): 5 , illetve 6 hónapos korában magas szemnyomások miatt trabeculectomiát végeztünk irisatrophia, elhúzott pupillák, csarnokzugi anomáliák miatt. 4 éves korában pupillaképzés történt a bal szemben. Szemnyomása kompenzált, szemnyomáscsökkentő egyszeri alkalmazása mellett. Látóélessége jó. Általános tünetek: craniofacialis dysmorphia, jelenleg fogászati kezelésre nem szorul.

Perzisztáló cavum septi pellucidi. Középvonali subarachnoidealis cysta.

Követési idő: 9 év. 
5. eset (leány): 2 éves korában bal oldali pupillaképzést végeztünk.

Posterior embryotoxon, a pupillák temporalis irányba elhúzottak. A szemnyomás napi kétszeri szemcseppentéssel kompenzált. Jó látóélesség. Általános tünetek: szükebb végbél, végbélsipoly (10-12. ábra).

Követési idő: 9 év.

6. eset (leány): Mindkét pupilla temporalis irányba helyezett, posterior embryotoxon látható. A szemnyomás jó, kezelésre nem szorul. Általános tünetek: a periumbilicalis bőr visszahúzódásának elmaradása észlelhető. Az arckoponyán minor anomáliák láthatók. Jó látóélesség mindkét oldalon.

Követési idő: 7 év.

7. eset (leány): 7 hónapos korában pupillaképzés történt a bal szemen corectopia miatt. Posterior embryotoxon mindkét oldalon látható. Szemnyomása az első kontrollok során a korának megfelelő normáltartományban volt, 2013 óta sajnos nem jár kontrollra.

Követési idő: 3 hónap, utána nem jelentkezett.

A ritka szemészeti kórképekkel küzdő gyermekek ellátása, gondozása centralizált kell, hogy legyen. A szemészeti vizsgálat természetesen nem nélkülözheti a réslámpás vagy csecsemókorban a mikroszkópos vizsgálatot, melyet olykor rövid, maszkos narkózisban szükséges elvégezni.

A gyermekszemész első feladatai közé sorolható a fénytörési hiba meghatározása és szemüveggel történó korrekciója, valamint a tompalátás kezelése a jobban látó szem megfelelő idejű takarásával.

A szaruhártya átmérőjének és a szemgolyó tengelyhosszának ellenőrzése mind az első, mind a kontrollvizsgálatok alkalmával szükséges. A megszokottnál gyorsabb növekedés utalhat szemnyomás-emelkedésre.

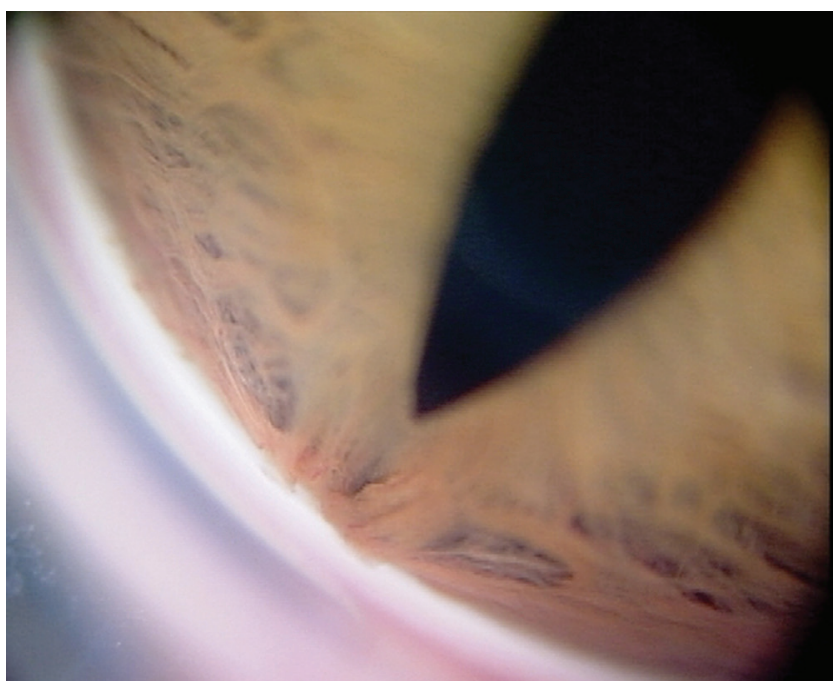

10. ábra

A széles iridocornealis adhaesio miatt elhúzott pupilla, mely rámutat a csarnokzugi abnormalitásra
A szemnyomás mérése kortól függően Icare (Ajaccio, Franciaország) vagy Tono-Pen készülékkel (Ametek Reichert Technologies, Depew, NY, USA), illetve 7-10 éves kortól a Goldmann-féle applanációs tonométerrel lehetséges. A glaucoma miatti szemészeti kivizsgálás része a csarnokzug vizsgálata (gonioszkópia) és esetleg objektív fotódokumentálása digitális kamerával (például RetCam Shuttle $^{\mathrm{TM}}$, Clarity Medical Systems, Pleasanton, CA, USA). Az elülső szegmentumot érintő fejlődési rendellenességek differenciáldiagnosztikájában az optikaikoherencia-tomográfiának (OCT) [5] (11. ábra) és az ultrahang-biomikroszkópiának (UBM) is szerepe van. Gyermekkorban a fenti vizsgálatok gyakran szintén csak altatásban végezhetők el.
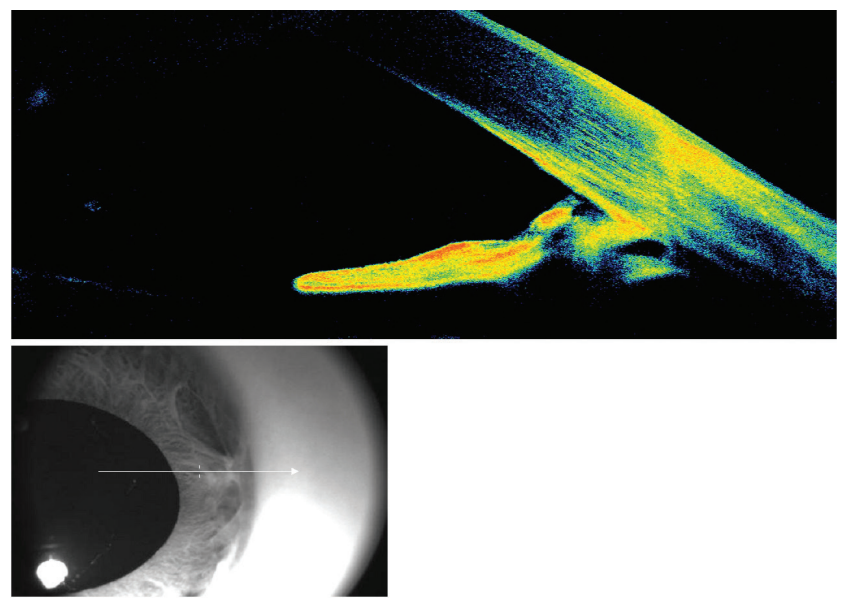

11. ábra | Iridocornealis adhaesio elülsőszegmentum-OCT-vel alkotott képe

OCT $=$ optikaikoherencia-tomográfia

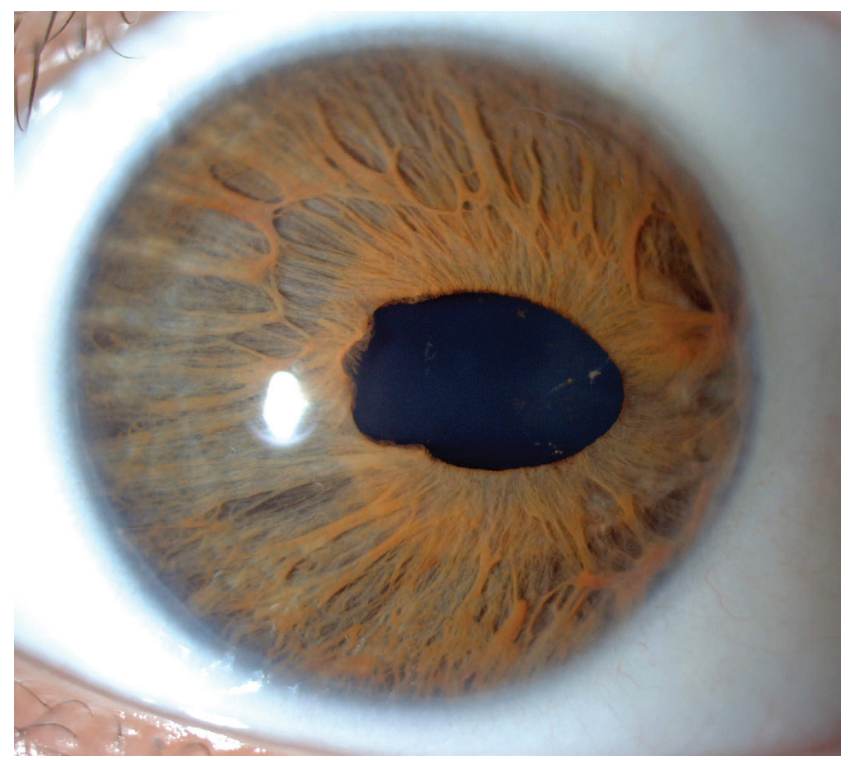

12. ábra

Pupillaplastica utáni állapot: VIII és X óra irányában sphincterotomia történt, így a centrum szabaddá vált 
Miután a zöld hályog bármely életkorban kialakulhat, hosszú távú betegkövetés és szükség szerint kezelés indokolt.

A zöld hályog miatt a fentieken túl a gondozás része a szaruhártya vastagságának mérése, a látótér vizsgálata és a hátsó szegmentum (papilla, macula) biomikroszkópos vizsgálata, valamint OCT-vizsgálata is. Ezen utóbbi vizsgálat jól kooperáló 7 éves gyermeknél már elvégezhető.

Microcoria vagy extrém corectopia esetén a tompalátás megelőzése érdekében sebészi úton pupillaképzés ajánlott (9. és 12. ábra). A mütétet gyermekkorban altatásban végezzük két kis (kb. 1,5 mm szélességü) seben keresztül mikroműszerek segítségével. Nagy molekulasúlyú viszkoelasztikus anyagot injektálunk az elülső csarnokba, mely biztosítja a szaruhártya endothelsejtjeinek és a szemlencsének a védelmét. Bár egyes szerzők biztonságosnak ítélték, mi nem tanácsoljuk a vitrectommal végzett pupillaképzést ezekben az esetekben.

A csarnokzugi rendellenességek miatt kialakuló szemnyomás-emelkedés egyes esetekben szemcseppekkel kielégítően befolyásolható. Gyermekkorban béta-blokkolót, karboanhidráz-inhibitort és prosztaglandin-analógot tartalmazó cseppeket nagy körültekintéssel alkalmazhatunk. Ebben az életkorban a2-adrenerg-agonistatartalmú szemcsepp rendelése tilos a központi idegrendszert érintő mellékhatások miatt.

Előfordul azonban, hogy a csarnokvíz elfolyását mütéti úton kell segíteni, és úgynevezett filtrációs mútétet (trabeculectomia) vagy úgynevezett hosszú tubusú sönt implantációját szükséges végezni [6]. A tubus helyzetének ellenőrzésére mind az ultrahang-biomikroszkópia, mind az elülső szegmentum OCT-vizsgálata alkalmas (2. és 3. ábra).

\section{További eltérések}

A rendszeres ellenőrzés egyéb szerveket érintő eltérések miatt is elengedhetetlen. A betegek ellátásához multidiszciplináris csapat szükséges.

A fizikális vizsgálat mellett genetikai vizsgálat is indokolt lehet. Az Axenfeld-Rieger-szindróma általában autoszomális domináns öröklődésmenetet mutat 95\%-os penetranciával és különböző expresszivitással. Genetikai szempontból három típusa különíthetô el:

1. típus: PITX2-gén (4q24-q26) mutációjával

2. típus: valószínúleg FOXOlA-gén (13q14) mutációjával

3. típus: FOXC1-gén (6p25.3) mutációjával

A FOXC1- és a PITX2-gén mutációja az összes eset 40-70\%-ában szerepel [7].

A hypophysist érintő rendellenességek közül kiemelendő a primer „empty sella” szindróma, az „izolált növekedésihormon-hiány alacsony termettel”, valamint a parasellaris arachnoidealis cysták jelenléte. Olykor szükség lehet a növekedési hormon pótlására is.

$\mathrm{Az}$ abdominalis régió is érintett lehet. Jellegzetes a periumbilicalis bőr visszahúzódásának elmaradása. Előfor- dulhat hypospadiasis, omphalokele, anusatresia vagy -stenosis. Akár már l éves kor előtt sor kerülhet a sürgős, életmentő sebészi beavatkozásokra.

A kardiológiai eltérések közül pitvari vagy kamrai septumdefektus, mitralis insufficientia fordulhat elő. Sensorineuralis halláskárosodást is észleltek.

Az Axenfeld-Rieger-szindrómát egyéb tünetegyüttesekhez társultan is megfigyelték (2. táblázat).

\section{Craniofacialis és fogazati jellemzők}

Az Axenfeld-Rieger-szindrómát a craniofacialis régió különböző eltérései jellemzik. Az agy- és arckoponyát érintő tünetek lehetnek a következők: előreugró homlok, hypertelorismus, telecanthus, lapos és széles orrnyereg; maxillahypoplasia miatti lapos arcközép, rövid filtrum, keskeny felső ajak és széles alsó ajak $[8,9]$.

Az „empty sella” és a parasellaris cysták kimutatására mágnesesrezonancia (MR)-vizsgálat szükséges. Egyes esetekben endokrinológiai felmérés és kezelés indokolt lehet.

$\mathrm{Az}$ állkapocs, valamint a fogazat szám- és alakbeli rendellenességei panoráma-röntgenfelvétellel jól dokumentálhatók. A dentalis anomáliák (4-6. ábra) közül számosat említenek a különböző publikációkban, mint például microdontia, hypodontia, oligodontia, anodontia, taurodontia és zománchypoplasia is $[9,10]$. A hypodontia egyaránt érintheti a tej- és a maradó fogakat, de a leggyakrabban a maxilla metszőfogainál, szemfogainál és

2. táblázat |A különböző tünetek szerinti differenciáldiagnosztika

\begin{tabular}{ll}
\hline Hypertelorismus & Costello-szindróma \\
& Floating-Harbor-szindróma \\
& Opitz G/BBB-szindróma \\
\hline Anodontia & Cerebrocostomandibularis szindróma \\
& Chondroectodermalis dysplasia \\
& Crouzon-szindróma \\
& Hallermann-Streiff-szindróma \\
\hline Hypodontia & Coffin-Lowry-szindróma \\
& Down-szindróma \\
& Hallermann-Streiff-szindróma \\
& Incontinentia pigmenti \\
& Oculodentodigitalis szindróma \\
\hline Opitz G/BBB-szindróma (hosszú, lapos) & Orofaciodigitalis szindróma (rövid) \\
& Robinow-szindróma (hosszú) \\
Williams-szindróma (hosszú)
\end{tabular}


3. táblázat |Fogászati beavatkozások Axenfeld-Rieger-szindrómában

\begin{tabular}{|c|c|c|c|}
\hline Életkor & Fogváltás & Beavatkozások & Fogászati team \\
\hline <l év & Tejfogazat & $\begin{array}{l}\text { Első fogászati látogatás } \\
\text { Otthoni higiénia gyakorlása } \\
\text { Prevenció }\end{array}$ & Gyermekfogorvos \\
\hline 1-6 év & Tejfogazat & $\begin{array}{l}\text { Periodikus orális vizsgálatok } \\
\text { A növekedés monitorozása } \\
\text { Ortopédiai korai kezelések } \\
\text { A megfelelő szájhigiénia fenntartása } \\
\text { Maxillaris expanzió: a metszőfogak és molarisok erupciójának segítése }\end{array}$ & $\begin{array}{l}\text { Gyermekfogorvos } \\
\text { Fogszabályozó szakorvos } \\
\text { Maxillofacialis sebész }\end{array}$ \\
\hline $7-12$ év & Váltott fogazat & $\begin{array}{l}\text { Szájhigiénia } \\
\text { Profilaxis } \\
\text { A fogszabályozó kezelés kezdése: } \\
\text { - az elülső és a hátsó keresztharapás korrekciója, } \\
\text { - a maradó fogak előtörésének segítése, } \\
\text { - 'reverse-pull headgear' kezelés } \\
\text { Bizonyos tejfogak eltávolítása, ezzel a maradó fogak erupciójának segítése }\end{array}$ & $\begin{array}{l}\text { Gyermekfogorvos } \\
\text { Parodontológus } \\
\text { Orthodontus } \\
\text { Maxillofacialis sebész }\end{array}$ \\
\hline 13-21 év & Maradó fogazat & $\begin{array}{l}\text { Fogászati vizsgálatok } \\
\text { Szájhigiénia } \\
\text { Profilaxis } \\
\text { Orthognath mútétek } \\
\text { Végleges fogászati ellátás (implantátumok, fogpótlások) }\end{array}$ & $\begin{array}{l}\text { Orthodontus, parodontológus } \\
\text { Maxillofacialis sebész } \\
\text { Fogpótlástani szakorvos }\end{array}$ \\
\hline >21 év & Maradó fogazat & $\begin{array}{l}\text { Retenció ellenőrzése } \\
\text { Orthognath mütétek ellenőrzése } \\
\text { Orális higiénia ellenőrzése }\end{array}$ & $\begin{array}{l}\text { Orthodontus } \\
\text { Maxillofacialis sebész } \\
\text { Parodontológus }\end{array}$ \\
\hline
\end{tabular}

második kisőrlőinél figyelhető meg. A fogak kónikus vagy csap alakú megjelenése sem ritka. A gyökerek megrövidülhetnek, a gingiva szövetei redukálódhatnak. Késői fogelőtörés és fogváltás jellemzi. A felső ajakfék hyperplasiája gyakori [11]. Fokozott gyökérfelszívódási hajlamot írtak le fogszabályozó kezelések után [12].

\section{A fogászati kezelés lehetőségei}

Az Axenfeld-Rieger-szindróma esetén is - mint számos más, a craniofacialis régiót érintő elváltozásnál - kulcsfontosságú a korai diagnózis és a gyermekkorban felállított pontos kezelési terv. Az érintett gyermekek fejlődésének és dentalis egészségének nyomon követése rendkívüli jelentőségú. Ök fogászati szempontból is speciális ellátást igénylő betegcsoporthoz tartoznak. Indokolt a szoros együttmúködés és a jó kommunikáció a szakterületek között, mivel a kezelés hossza nehézséget jelent a páciensnek és családjának, ütközhet az egyéb orvosi beavatkozásokkal (szemészeti és gastrointestinalis mütétek), ami szintén megterhelő a páciens számára. Az egyes üléseknek a lehető leghatékonyabbnak kell lenniük.

Nem ritka, hogy ezeknél a gyerekeknél a mentális érintettség vagy a rossz szociális háttér miatt altatásban vagy bódításban végzik az egyszerű fogászati beavatkozásokat, a konzerváló fogászati kezeléseket (tömések, gyökérkezelések) vagy a tejfogextrakciókat. A fogak mellett általában az agy- és arckoponya többi területe is érintett, ezért többek között 'cone-beam' komputertomográfia (CBCT) és cefalometriai vizsgálatok alapján dönthető el, hogy szükség van-e sebészi korrekcióra vagy sem (5. ábra). A fogszabályozó kezelések elengedhetetlenek. Az ortopéd fogszabályozó kezeléseket már a váltófogazat idején el kell kezdeni. A teljes fogászati rehabilitáció a beteg 18. életévének betöltése után lehetséges, mert az implantátumon elhorgonyzott fogpótlások a csontnövekedés befejeztével lehetségesek (3. táblázat).

\section{Következtetés}

Az Axenfeld-Rieger-szindróma diagnózisának korai felállítása a szemészeti és fogászati eltérések alapján speciális ellátóhelyen, megfelelő centrumokban nem okozhat problémát.

A maradó fogak csírahiánya, valamint a maxillahypoplasia miatt jelentkező harmadosztályú basalis sagittalis viszony és ezáltal a nem megfelelő occlusio sok esetben gátolja a mindennapi táplálkozást is. A csarnokzugi eltérések következtében kialakult zöld hályog a látási funkciók csökkenését okozhatja. Mivel a betegség már korai gyermekkorban manifesztálódik, a társadalmi beilleszkedés is nagy nehézséget jelenthet. Ugyanakkor mind a gyermekekre, mind a szülőkre pszichés terhet is ró a folyamatos ellenőrzéseken való megjelenés, amely megfelelő szociális hátteret is feltételez.

A témakörben jártas szakembereket speciális felszereltség, megfelelő aneszteziológiai háttér segíti. Mindezek teszik lehetővé, hogy megfelelő időben elvégezhessük a szükséges mütéteket és kezeléseket, melyek jelentős életminőség-javulást biztosíthatnak, de nem minden esetben. 
Anyagi támogatás: A közlemény megírása, illetve a kapcsolódó kutatómunka anyagi támogatásban nem részesült.

Szerzői munkamegosztás: B. M., M. E., N. O.: A szakirodalom kutatása és elemzése, a kézirat elkészítése, szerkesztése. Cs. B., Cs. M., N. Z. Zs.: A kézirat szerkesztése. A cikk végleges változatát valamennyi szerzó elolvasta és jóváhagyta.

Érdekeltségek: A szerzőknek nincsenek érdekeltségeik.

\section{Köszönetnyilvánítás}

A szerzők köszönetet mondanak a Peter Cerny Alapítványnak, hogy a csarnokzugi felvételekhez rendelkezésünkre bocsátották a digitális szemfenéki kamerát, valamint Széles Évának az elülső szegmentum réslámpás fotóinak elkészítéseért.

\section{Irodalom}

[1] Shields MB, Buckley E, Klintworth GK, et al. Axenfeld-Rieger syndrome. A spectrum of developmental disorders. Surv Ophthalmol. 1985; 29: 387-409.

[2] Dada T, Sidhu T, Kumar A, et al. Gonioscopy: a video assisted skill transfer approach. Jaypee Brothers Medical Publishers, New Delhi, 2016.

[3] Idrees F, Vaideanu D, Fraser SG, et al. A review of anterior segment dysgenesis. Surv Ophthalmol. 2006; 51: 213-231.

[4] Kelberman D, Islam L, Holder SE, et al. Digenic inheritance of mutations in FOXC1 and PITX2: correlating transcription factor function and Axenfeld-Rieger disease severity. Hum Mutat. 2011; 32: 1144-1152.

[5] Wang D, Wang M, Console JW, et al. Distinctive findings in a patient with Axenfeld-Rieger syndrome using high-resolution AS-OCT. Ophthalmic Surg Lasers Imaging 2009; 40: 589-592.

[6] Mandal AK, Pehere N. Early-onset glaucoma in Axenfeld-Rieger anomaly: long-term surgical results and visual outcome. Eye (Lond). 2016; 30: 936-942.

[7] Shánchez Ferrer F, Grima Murcia MD. Progressive moderate mitral regurgitation in a children with Axenfeld-Rieger syndrome. The importance of cardiologic follow up. [Insuficiencia mitral moderada progresiva en un niño con síndrome de AxenfeldRieger. Importancia del seguimiento cardiológico.] Arch Argent Pediatr 2016; 114: e417-e420. [Spanish]

[8] Fan Z, Sun S, Liu H, et al. Novel PITX2 mutations identified in Axenfeld-Rieger syndrome and the pattern of PITX2-related tooth agenesis. Oral Dis. 2019; 25: 2010-2019.

[9] Pirih FQ, Casarin M, Perussolo J, et al. Rieger syndrome: rehabilitation with dental implants. Clin Adv Periodontics 2019; 9: 172-176.

[10] Seifi M, Walter MA. Axenfeld-Rieger syndrome. Clin Genet. 2018; 93: 1123-1130.

[11] Bender CA, Koudstaal MJ, van Elswijk JF, et al. Two cases of Axenfeld-Rieger syndrome, report of the complex pathology and treatment. Cleft Palate Craniofac J. 2014; 51: 354-360.

[12] Dressler S, Meyer-Marcotty P, Weisschuh N, et al. Dental and craniofacial anomalies associated with Axenfeld-Rieger syndrome with PITX2 mutation. Case Rep Med. 2010; 2010: 621984 .

(Bausz Mária dr., Budapest, Mária u. 39., 1085 e-mail: bauszmaria@t-online.hu)

\section{"Voluntas impudicum non corpus facit." (Szégyentelenné nem a test, az akarat tehet.)}

A cikk a Creative Commons Attribution 4.0 International License (https://creativecommons.org/licenses/by/4.0/) feltételei szerint publikált Open Access közlemény, melynek szellemében a cikk bármilyen médiumban szabadon felhasználható, megosztható és újraközölhető, feltéve, hogy az eredeti szerző és a közlés helye, illetve a CC License linkje és az esetlegesen végrehajtott módosítások feltüntetésre kerülnek. (SID_1) 